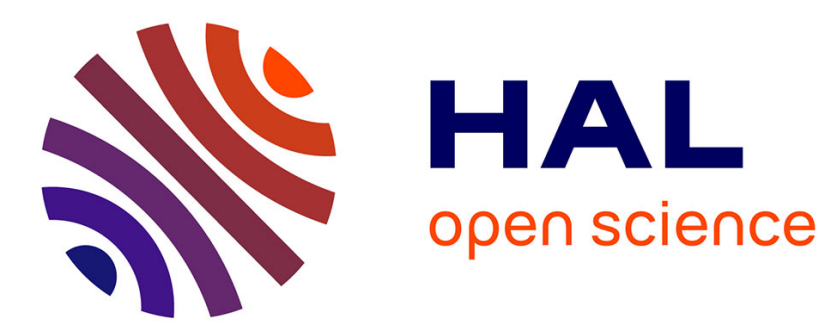

\title{
From Learning to Rationalization: the Roles of Accounting in the Management of Parisian Great Exhibitions from 1853 to 1902
}

Karine Fabre, Céline Michaïlesco

\section{- To cite this version:}

Karine Fabre, Céline Michaïlesco. From Learning to Rationalization: the Roles of Accounting in the Management of Parisian Great Exhibitions from 1853 to 1902. Accounting, Business and Financial History, 2010, 20 (1), pp. 67-90. halshs-00540569

\section{HAL Id: halshs-00540569 \\ https://shs.hal.science/halshs-00540569}

Submitted on 27 Nov 2010

HAL is a multi-disciplinary open access archive for the deposit and dissemination of scientific research documents, whether they are published or not. The documents may come from teaching and research institutions in France or abroad, or from public or private research centers.
L'archive ouverte pluridisciplinaire HAL, est destinée au dépôt et à la diffusion de documents scientifiques de niveau recherche, publiés ou non, émanant des établissements d'enseignement et de recherche français ou étrangers, des laboratoires publics ou privés. 


\title{
From Learning to Rationalization: the Roles of AcCounting in the MANAGEMENT OF PARISIAN GREAT EXHIBITIONS FROM 1853 TO 1902
}

\author{
Karine Fabre - ATER - Paris Dauphine \\ Céline Michaïlesco - Maître de conferences - Paris Dauphine
}

\section{Introduction}

The five Universal Exhibitions held in Paris between 1855 and 1900 share the particularity of having been, unlike their British counterparts, financed first wholly, then in part, by the Government. Public financing led to public finance principles (budgetary and public accounting) being applied to the organisation of the Exhibitions. Along with these, the organisation in charge of running these events imported a set of well-formatted techniques. However, these techniques (budgeting and accounting technique) were part of a highly specific type of organisation that bore all the hallmarks of a project:

- an Exhibition is characterised by strong notions of vision, intentionality and voluntarist action: it seeks to achieve objectives (of presentation/democratisation and dissemination) which require a certain number of specific activities to be set up, the results of which, subject to uncertainty or exogenous variables, must be measured both as preparations advance, and then again retrospectively, after the event.

- an Exhibition is an event limited in time and space (it opens on a given date and for a length of time decided by the law (or decree) and its organisation is traditionally divided into four well-defined phases: preparation, realisation, exploitation and liquidation.

The principles of public finance must therefore be adapted to a specific organisational environment and in particular, to the managerial constraints of the event. The system of accounting information is very much part of a process of organisational perception, governance and strategic mobilisation. The Universal Exhibitions provide an original field of investigation for examining the roles attributed to accounting within the framework of the organisation of such events. The originality here derives as much from the context (a project to be managed over a period of time and where no tool or project management model existed (Michaïlesco, 2007)) as from the public nature of the accounting technique used. Indeed, since knowledge of public accounting practice is incomplete, the study of organisation by the state would seem extremely interesting for the history of public finance (Thuillier, 1999). From this point of view, the Universal Exhibitions organised in Paris during the second half of the 19th century were organised under two different political regimes and within two distinct public finance frameworks. Changes in the regulations governing public finances had an impact on the powers bestowed on the organisations in charge putting on the Exhibitions. The accounting systems which were set up therefore had to be adapted to fit within the time limit. Moreover, public accounting was designed with the aim of controlling the collection of taxes and their use (Lemarchand, 1999), which is different from running an Exhibition, in particular if the event is seen in terms of project management. This change of objective modified the use of accounting systems and led to the emergence of specific roles that had to evolve as a result of both the accumulation of knowledge and the political context.

The aim of this article is therefore to analyse the role of public accounting within the framework of the five Universal Exhibitions organised in Paris during the second half of the 19th century. The analysis was carried out using Burchell \& al.'s classification system (1980). The latter distinguishes between four types of role assumed by accounting systems with reference to the characteristics of decision-making within an organisation. Indeed, decision-making is affected by adhesion to an objective and the uncertainty surrounding the consequences of the action taken. Depending on the degree of adhesion and uncertainty, decision-taking is described as 'decision by computation', 'decision by judgement', 'decision by compromise', or 'decision by inspiration'. The roles of accounting ascribed to these are as follows: 'answer machines', 
'learning machines', 'ammunition machines' and 'rationalization machines'. Two groups of Universal Exhibitions have been identified: those held under the Second Empire (the 1855 and 1867 Exhibitions)

and those held under the $3^{\text {rd }}$ Republic (the 1878, 1889 and 1900 Exhibitions). This division into two main periods allows us to take two important factors into account: on the one hand, the change of political regime that influenced the rules of public finance and on the other, the constitution of fairly general principles for the running of these events. The comparative study of these two groups of Exhibitions reveals that two distinct roles can be allotted to the accounting systems: a learning role during the Exhibitions of the first period, then a rationalization role in the case of the Exhibitions held during the second period.

Under the Second Empire, the Universal Exhibitions financed exclusively by the Government were supported by strong political, economic and social aims. The importance given to holding such an event distanced these projects from control by Parliament, whose influence had already been weakened considerably under Napoleon III. Although the decision to organise an Exhibition was unanimous, lack of knowledge on how to run such a project meant there was great uncertainty as to the consequences of decisions since the concept was new. Experience of running such a wide-ranging project therefore had to be acquired. An accounting system based on the rules and principles of public accounting and adapted to the events in question therefore met these needs. Within the framework of the Universal Exhibitions organised under the Second Empire, accounting may therefore be analysed as a learning instrument and aid to decision-making (learning machine).

The arrival of the $3^{\text {rd }}$ Republic and with it the return of strict parliamentary control, saw great controversy emerge as to the economic usefulness of Universal Exhibitions and the financial implication of the Government in their organisation. The difficulty in obtaining a consensus on how they should be run led to a process of retrospective justification in which accounting acquired considerable importance. Despite the financial disengagement of the Government, the principles of public finance were still applicable but had evolved as a result of changes in the political and economic environment. Experience acquired in the organisation of the preceding Exhibitions reduced the uncertainty inherent in evaluating the consequences of decisions taken. However, the need then arose to rationalize the existence of these events and the use of the private finances obtained. Budgetary procedures were strengthened and there was an overproduction of information in the shape of financial reporting and statistics. In this context, the accounting system, which had been adapted many times after the first Exhibitions as a result of changes in the environment, was then used to rationalize the action taken (rationalization machine).

The documents used to carry out this study are of two different kinds. On the one hand, there are the various documents generated by the organization of the Exhibitions (correspondence, plans of the exhibition palaces, photographs, administrative and accounting documents etc.) that were presented to the national archives by the Ministry for Commerce between 1877 and 1910 (de Maurepas, 1998). In addition to these documents there are the official reports written by the general commissioners of the successive Exhibitions assessing the organisation of the events and the results (these reports are available in the Bibliothèque Nationale de France and the Bibliothèque des Arts Décoratifs).

In order to highlight the changes in the roles assumed by accounting systems in the management of Great Exhibitions, the next section deals with the Great Exhibitions held during the Second Empire when the accounting system fulfilled the role of a learning machine thus helping to acquire the experience lacking at the beginning. The following section examines how this role changed into a rationalization machine due to political and parliamentary control background during the Third Republic. The final section contains a few concluding observations on accounting roles in a specific project management both in terms of nature and period of time.

\section{Accounting as a learning instrument for decision-making in project management: the Universal Exhibitions of the Second Empire (1855 and 1867)}

The decision to hold the Universal Exhibitions of 1855 and 1867 was taken by the Emperor Napoleon III who wanted to see events of the type which were so successful in London in 1851 and 1862, held in Paris. 
The decrees announcing the Exhibitions were issued in 1853 and 1865 and fixed the opening date and the length of time they would run. An Imperial Commission was created to plan and run these events along the general lines set out in London by Prince Albert: the presentation of products issuing from industry and the arts, the attribution of prizes and temporary buildings. The difference between the London and Paris Universal Exhibitions was that the latter were put on using exclusively public finance, hence the application of the rules of public finance for the financial management of the Exhibitions.

\subsection{Intentionality and organisational uncertainty in the Universal Exhibitions of the Second Empire (1855 and 1867)}

From the point of view of the decision-making process, a study of the Exhibitions organised under the Second Empire, reveals two major characteristics, using the classification of Burchell \& al. (1980). There is a strong intentionality underpinning the holding of an Exhibition of this type in Paris but also a total lack of knowledge of the consequences of decisions resulting from the "universal" dimension of the concept.

\subsubsection{A pervading consensus on the usefulness of holding a Great Exhibition.}

Several elements may be put forward to affirm the strong adhesion to the objectives that characterise the Exhibitions organised under the Second Empire - arguments that are economic, social and political in nature. This strong degree of intentionality can be seen in the total autonomy given to the Imperial Commission created to organise each Exhibition.

A tradition of Exhibitions dedicated to the products of industry had existed in France since the Directory: the first Exhibition of the products of French industry was held in the Champs-de-Mars in 1798 on the initiative of François de Neufchâteau. These Exhibitions, systematically organised by the Minister of the Interior or the Minister of Commerce and Agriculture in association with the Minister for the Arts, were considered necessary to boost industry and French design. Following the huge success of the London Universal Exhibition, which was one of a series of national Exhibitions, the French government decided to try out the concept in Paris because it would allow them to display the elements at the heart of the Government's economic and social policy: develop the regions and education, launch a creative dynamic in industry and the arts, and promote free trade. The importance of these broad areas of State policy was generally accepted on account of France's backwardness (infrastructures, etc.) compared to other countries such as Great Britain. (Marion, 1928, 1931; Orsoni, 1994). The commitment of directors of major French companies (the number of which rose from 5 under the Imperial Commission of 1855 to 23 in that of 1867), underlines the existing conviction of the economic usefulness of these events.

The fact that the State was involved in the organisation of the Exhibitions was no longer disputed in financial terms: this point of view was expressed by the Minister for Agriculture and Commerce with regard to the 1867 Exhibition:"from a financial point of view, the Government would have nothing to gain from relinquishing all influence on the preparation and running of the operation and moreover, one might be permitted to doubt that such a withdrawal would benefit the impact, utility and success of the Exhibition (Le Play, 1869, p. 644)". By financing the Exhibitions, the State generated a dynamic which did not then exist in France for organising wide-ranging projects and from this point of view also, the Exhibitions were useful: "In France, capitalists often lack boldness, or when they decide to enter into business, they are frequently lacking in morality and intelligence (Prince Napoleon, 1857: 136-137)".

The Universal Exhibitions were also underpinned by strong political ambition. They cannot be separated from Napoleon III's important political project that focused on "conquering" the working classes (Rebérioux, 1983). This ambition is evident in all the Universal Exhibitions organised in Paris under the Second Empire (in the choice of ticket prices, in the implication of Frédéric Le Play and in the themes chosen) and in the foreign Universal Exhibitions in which France participated (constitution of workingclass delegations for the 1862 Exhibition in London).

The importance bestowed on holding an Exhibition founded on economic and political arguments, was 
combined with a weakening of parliamentary control under the Second Empire. Indeed, when he came to power, Napoleon III, wanted to free himself from the constraints resulting from this control (delays, personal interests, local stipulations) which had proved damaging to the realisation of major public interest projects during the Restoration (Marion, 1928). It would seem the Exhibitions were perceived as large-scale projects placed directly under the control of the Emperor and not of Parliament. The Imperial Commissions created by the Emperor to organise events were therefore totally autonomous: they had deliberative and executive power: the Emperor merely ratified all the decisions taken.

\subsubsection{Understanding the consequences of action in the creation of an Exhibition}

In contrast to the unanimity expressed on the importance of holding an Exhibition in Paris, knowledge of cause and effect between decisions and results was inexistent. The difficulties encountered in drawing up budgets clearly show this prevalent uncertainty concerning the consequences of choices both in the evaluation of revenue and of expenses. Expenses include all the activities that enable the Exhibition to be held: operational activities (construction of buildings, price commissions, events, conferences, etc.) and support activities (accounting, security, cleaning, etc.). Revenue includes the entry fees and concessions (rent for sites from restaurants and exhibitors, advertising sites, the right for hawkers to sell, the use of gas and water, etc.). The resale of materials from the palace and park when the exhibition came to be dismantled was another source of uncertain revenue generated by the Exhibitions.

The evaluation of risks in the elaboration of the overall budget was difficult because these impacted on three aspects of the project: quality, time limits and the cost, and increased the possibility of needing further credit. When Paris was organising its first Universal Exhibition in 1855, the Imperial Commission was inexperienced (Prince Napoleon, 1857: 249). Budgeting was mainly based on the figures reported by the Universal Exhibition in London, the only precedent available to guide the organisers. Forecasting was therefore poor and partial:

"before formulating the expenses written into the draft budget attached, we had to examine the expenses incurred at past Exhibitions and especially that held in London, the only precedent that can serve as a framework for a universal exhibition. The London Exhibition showed a sum of 7,319,863 francs and 55 centimes including, truth to tell, the construction of the Crystal Palace which alone amounted to 4,429,968 francs and 20 centimes. There remains, therefore, for the organisation and running of this exhibition, spending of 3,069,895 francs and 35 centimes which will serve as the basis of our forecasts...".

The 1855 Exhibition was a financial failure. Lack of experience prevented the necessary expenses attendant on the organisation of the event to be accurately assessed. Prince Napoleon, President of the Imperial Commission, regretted this outcome and insisted on the need to forecast expenses and revenue more accurately for future Exhibitions so that the budget would not be exceeded.

From the point of view of revenue, a choice unprecedented in France was made from the outset to demand an entrance fee to the Exhibition:

"I consider an entrance fee to be an equitable measure. Instead of imposing on the whole nation an expense that benefits only part of it, we are imposing it on those who benefit from it. In the last analysis, someone must always pay. Placing the financial burden on the State instead of the public who benefit from the Exhibition, is to impose a tax on everyone, that is to say the craftsmen and the farmers in the Département as well as the inhabitants of the Capital, to cover an expense from which the former will derive no immediate benefit (Prince Napoleon, 1857, pp. 81-82)".

Two types of uncertainty then emerged centering on the entrance fee and the number of potential visitors. In 1867, fixing the entrance fee was already extremely important because according to the exhibition's organiser, the low revenue generated by the 1855 exhibition was due to inaccurately setting the ticket prices. So instead of 0.65 francs, the organiser suggested an average price of 1.15 francs. Finally, in the budget approved by the Imperial Commission on $6^{\text {th }}$ April 1865, the price adopted was 1 franc (by way of 
comparison, the average price imposed in London in 1862 was 1.65 francs). Fixing the entrance fee caused the general organiser to remark:

“ $\{\ldots\}$, the entrance fee demanded for an event that is unique in the world is totally insignificant if we compare it to the considerable expenses that workers in Paris pay every day for shows that are infinitely less interesting. But there is nothing to prevent the Imperial Commission from taking special measures to ensure that the working classes can visit the Exhibition in the very rare cases where this price, modest though it may be, is considered unaffordable".

The number of visitors remained an uncertainty that the Commission could not remove, but it was particularly prevalent in the first two Exhibitions in that behaviour had to be created, rather than learned, since Parisians were not used to paying to see an Exhibition unlike the English (Prince Napoleon, 1857:81). The uncertainty as to the number of visitors combined with that over entrance prices, directly influenced the amount of revenue and in the end, the subsidy to be provided by the Government.

Forecasting construction expenses, the most onerous item on the budget, raised two problems: that of estimating the number of exhibitors and thus the amount of space to be developed, and the revenue from the resale of the materials from the palace. Observations were based both on what had been done for preceding exhibitions and on architects' estimates. Assessing the surface area of the exhibition stands was difficult. The estimates were often insufficient as a result of underestimating the participation of the various countries, and this was especially true of the first exhibition:

"The Imperial Commission was dominated by necessity: the inadequacy of the Palace was the reason why unexpected expenses were so enormous that extra credits inflated the first estimates (Prince Napoleon, 1857, p.125)».

The architectural choices made for the Palace were also a source of uncertainty. In 1867, Le Play designed a circular building and the resale of curved materials was to pose a problem and decrease the revenue obtained from the final sale of the materials from the construction of this building. Unanimity on the economic, political and social usefulness of holding an Exhibition together with total misunderstanding of the qualitative and financial consequences of the choices that could be made for its organisation led to 'decision by judgement' (Burchell \& al., 1980). The successive Commissions in charge of the organisation were obliged, in view of the aim of opening the event on a prescribed date and for a given period, to take decisions by subjectively estimating the consequences of their decisions. This was all the more difficult since the project was a wide-ranging one requiring a variety of skills. Moreover, there was no doubt in the minds of the organisers that these events would be repeated on account of their contribution to national prestige. The aim was therefore also to acquire experience that would be useful for subsequent Exhibitions:

" the Exhibition was expensive because we did not act together from the beginning and we had to resort to expedients of all sorts. I can confirm that a new Universal Exhibition put on in Paris under better conditions would not incur one third of the expenses required by that of 1855 (Prince Napoleon, 1857, p.126) ».

The principles which were automatically applied with public finance were to take on the role of a « learning machine » as defined by Burchell \& al., (1980).

\subsection{The learning role played by the accounting model set up for the Universal Exhibitions organised under the Second Empire}

In order to explore the different facets of the « learning machine » role assumed by the accounting system of the Universal Exhibitions of this first period, we begin by defining the characteristics of the accounting model that was implemented. When the Imperial Commissions were created, administration systems had to be defined. Within these systems, the rules of public accounting necessarily implied certain methods 
which were then adapted to the specific needs of administration.

\subsubsection{Adaptation of the public accounting model}

The period of the Second Empire seems to represent a parenthesis in the process of the affirmation of parliamentary control over public finances. Napoleon III hoped, when he came to power, to free himself from the constraints attached to this control (length, personal interests, local requirements) which proved damaging to the mounting of major public interest projects during the Restoration (Marion, 1928). The Emperor allowed himself to allocate special credits for major projects without authorisation from Parliament (Caudal, 2004). The Exhibitions were therefore placed directly under his control and not that of Parliament. The Imperial Commissions created by the Emperor in order to organise the events were therefore completely autonomous. However, the expenditure of public funds called for the application of the principles of public finance. The allocation of public subsidies was dependent on the elaboration of an overall budget which was then audited to check that the use of funds conformed to the approved budget. An accounting model was drawn up based on these principles then adapted to the demands of managing such a specific project.

\subsubsection{Budgetary procedure}

Although the Imperial Commission created for the purpose of organising the Universal Exhibitions was totally autonomous and its decisions ratified directly by the Emperor, measures were laid down in order to introduce a budgetary procedure. During the Exhibition of 1855, members of the Imperial Commission were designated by its President to make up a sub-commission in charge of the elaboration of the overall budget. The budget proposal was then examined and debated by the Imperial Commission, which had a deliberative function, until its final approval: the object of the debate was to ensure that the expenses and revenue items were justified and to approve their assessment. A form of control by peers was thus set up and was a substitute for Parliamentary control. The President of the Commission held executive power, and validated the overall budget which was then directly ratified by Imperial decree.

During the organisation of the Exhibition of 1855, an effective administrative structure was sought and gradually took shape with the emergence of the function of general commissioner. From then on, this function characterised the organisation of Universal Exhibitions in France. The general commissioner was in charge of drawing up the overall budget. This was then examined by the Finance Committee who presented it for approval to the Imperial Commission. The existence of these committees was justified by the amount of specific information that had to be processed for the project to move forward:

"In the recurring form that is specific to [Great Exhibitions], each of them is an increasingly large task that has to be carried out within a short space of time and for a limited period. In just a few months, a temporary administration structure has to be organised, the elements of which are ill-prepared and can only be found with difficulty. This improvised administration structure must nonetheless suffice for a task that requires a great deal of work and the nature of which changes as the undertaking advances (Le Play, 1869, p.269) ».

The Finance Committee provided an arena for a preliminary level of debate on the items of expenses and revenues identified by the General Commissioner and the questions raised, from a financial point of view, by the organisation of an Exhibition. It met, moreover, the legal obligation imposed by the reform of public accounting in 1862.

On the other hand, Parliamentary control meant extra credits had to be refused. This constraint proved impossible to maintain during the first Exhibition of 1855. Indeed, the political dimension of the Exhibitions was sufficiently prominent for the Imperial Commission not to take it into consideration. However, it was preserved as a moral constraint and was highlighted by Le Play during the organisation of the1867 Exhibition:

«The aim pursued by the founders being too lofty for them to bother about such a consideration (making a 
profit); but essentially, it is important to avoid a deficit that would have to be compensated for by extra subsidies to be requested from the Government and the City of Paris [Le Play, 1869, p.250] ».

It was with this in mind that a guarantee association was created.

\subsubsection{The rules of public accounting}

Public accounting was frequently regulated during the first half of the $19^{\text {th }}$ century, resulting in the elaboration of a real accounting code under the Second Empire that was applied to the Universal Exhibitions under study. The Exhibitions, like the Government, were governed by accounting regulations, drawn up when the idea of an event was launched. These regulations, under the terms of the 1838 Public Finance Enactment, covered the preparation and approval of the budgets, procedures for dealing with expenses and their payment, and the setting down of general accounts and accounts to be kept by the organisers and accountants and the responsibilities of the latter (Magnet, 1995). The Regulations prescribe the procedures and rules laid down in the texts on public finances and accounting (The Decree of May 1862 revising the 1838 Order):

- The separation between the organiser and the accountant so that checks were separate from the expense itself. In the case of the Exhibitions, the general commissioner was a secondary authority. He authorised the expense but only the accountant could carry it out. So it was possible to run checks on both the commissioner and the expense (De Swarte, 1885). The general commissioner was responsible to the Minister of Finance;

- Double entry accounting, the sole aim of which was to check the reality and conformity of the expenses with their object (Lemarchand, 1999). For this, documentary evidence (Orders, Mandates) was compulsory and no payment could be made without it. It was therefore mentioned in the accounts or accounting documents;

- Retrospective checks based on the production of periodical documents (monthly balance-sheets submitted to the President of the Imperial Commission) and summaries (a general account of the revenue and expenses relating to the Exhibition submitted for the approval of the Imperial Commission before being presented to the Emperor).

Under this system, the finance committee created for the 1867 Exhibition under the terms of Article $\mathrm{n}^{\circ} 192$ of the 1862 Decree had the task of following accounting operations and the cash flows. When the Exhibition closed, a sub-committee created to audit the books submitted a report to the finance committee in charge of presenting its conclusions to the Imperial Commission and thereby discharging from his responsibilities the Director of the accounting department.

\subsubsection{The Accounting System implemented}

Article $n^{\circ} 374$ of the 1862 Decree assigned two objectives to public accounting: on the one hand, checks on the reality of the accounting records (through double entry) and on the other, the elaboration of the general Government budget by collecting and storing information on expenses and revenues. To do this, an organised system of accounting books was implemented. Article 22 (Title 4) of the Rules of Accounting for the Exhibition of 1867 stipulates that the accounting books to be kept are:

" [...] a general journal, a ledger and sub ledgers. The general journal only contains the general accounts and summary results: developments are consigned to the sub ledgers whose number and form are determined by the nature of the services».

This general rule was then developed to meet the practical requirements of the Exhibition's accounting and financial administration. Industrial accounting practices were taken into account within this development so as to obtain an information system that met the two objectives of public accounting. The books needed to keep the accounts were organised according to a centralising system laid down by 
Desarnaud de Lésignan (Vlaeminck, 1979). A summary of the organisation of the accounting books for the 1867 Exhibition (cf. schema 1) explains the way this centralising system worked:

- at the lowest level were the sub ledgers: the subscription journal, revenue ledger, accounts ledger, entrepreneurs' accounts, the expenses ledger, and the cash book. At this first level, the revenue ledger, expenses ledger and the cash book, which are themselves on a higher level, can be singled out.

- at a higher level is the combined journal and ledger that summarises operations. This general ledger bears witness to the impact that ideas on the columns systems and classifications had on accounts during the $19^{\text {th }}$ century. Indeed, the layout of the general ledger was welcomed because it brought together two documents and could be adapted to the need for information of traders and industrialists (Nikitin, 2005).

The originality of this centralising system was to place the general budget of revenue and expenditure to which the revenue and expenditure ledgers refer at the beginning of the process (in the same way as the combined ledger and journal is the culmination).

The recourse to industrial accounting practices to deal with the information processing function was visible in the specific classification into fifteen accounts used in the accounting books of the 1867 Exhibition: Cash, General Expenses, Real Estate Credit on current account, Real Estate Credit (guarantee company), Construction of the Exhibition Palace, Entrepreneurs, State Subsidy, Subsidy of the City of Paris, Revenue from the Exhibition, Subscribers to the Guarantee Association, Setting up of the Exhibition Centre, Platform and setting in motion of the machines, Capital, Profits and Losses, Miscellaneous. These accounts were influenced by the elder Desgranges through the "Profits and Losses " and «Capital » accounts. However, the centralising system also included the manufacturing accounts (accounts by destination) with the "Construction of the Exhibition Palace » and "Setting up of the Exhibition Centre », various costs accounts that are not only goods accounts, and various third-party accounts ("Subscribers to the Guarantee Association, Entrepreneurs, etc.) The interesting point about these accounts is that they are modelled on the main expense categories of the budget (the combined Journal and Ledger, was, in fact, designed and printed for the Exhibition), which meant expenses could be monitored and checked in accordance with the requirements of public accounting.

(Insert diagram 1)

\subsubsection{Aspects of the 'learning machine' role fulfilled by the accounting model}

The 'learning machine' role that characterises the accounting system elaborated during these two big Exhibitions can perhaps be analysed under three main headings. The lessons it provides lie just as much in the coordination of the various activities involved in the organisation as in the understanding of the accumulation of expenses generated by these activities and in creating a schedule.

\subsubsection{Structuring the Organisation}

The accounting information system elaborated within the framework of the Universal Exhibitions met the need to make the consequences of decisions taken visible in economic terms and to allow the organisation to be governed in a way that matched the desired result: that of creating an Exhibition to open on a given date (Hopwood, 1987).

The governance of the organisation of the Exhibition was a major preoccupation during the first Exhibition. Indeed, the President of the Imperial Commission was interested in a model along the lines of the British example that he had studied during the 1851 London Exhibition and which favoured decentralisation. The President of the Imperial Commission created seven specialist departments each with its own commissioner. The seven commissioners formed an executive committee presided over by one of its members. The aim of this organisation, similar to the one set up in London was to "bring 
together all the elements of the initiative into the same sphere, making them constantly available (Prince Napoleon, 1857: 20) ». However, this executive committee was rapidly replaced by a general commissioner, a cog considered unnecessary by Prince Napoleon but in which he recognised a typically French tendency towards centralisation as the only means of obtaining group action. From then on, the general commissioner occupied a central position: he coordinated the operational and administrative activities that were organised into departments under the control of the Imperial Commission whose members were grouped into specialist steering committees whose task was to help, advise and carry out checks. A functional structure was set up that combined two characteristics:

- a trade-specific decision-making line reflecting the classification adopted by the Exhibition (Agriculture, parks and gardens, roads and bridges, Fine Arts, etc.) which included general services (litigation, general secretariat);

- a 'project' decision-making line : a general commissioner directed the major functions and ensured coordination by means of committees, heads of departments, directors and specialist committees. A general commissioner supervised « more fully the unity of purpose and spirit that is indispensable for success, to establish better harmony between the various parts of a body that is eminently complex in nature and in the elements of which it is made up (Picard, 1901, p. 24) ».

This type of organisation meant that everything was directed upwards towards the general commissioner who coordinated all the aspects of the project with the aim of ensuring that all efforts converged on the set objective. The coordination model was therefore centralised and hierarchical. The centralisation and hierarchy that characterised the administrative organisation of the Exhibition reappeared at the accounting level where the system of the centralising Journal was predominant. The setting out of the accounting books reflected the functional segmentation of the organisation of the Exhibitions (Hopwood, 1987).

A parallel may, moreover, be drawn between the centralising Journal of the 1867 Exhibition that offered an overall vision of the use of the credits and the progress of the project and the plan adopted for the building of the Exhibition itself. Indeed, the circular nature of the building enabled, in the view of the general commissioner who designed it, to facilitate comparative study and review the various groups of products in the same way that the centralising Journal offered these same possibilities. The fitting of the accounting information system into the organisation became a means of observing the route taken by the project towards its destination in relation to the initial understanding of the route laid down in the overall budget (cf. schema 1). The budget can be seen as a means of observing the organisation in economic terms. It was from this angle that Le Play saw budgets. As part of his social method, they are a real tool for understanding the life of the working-class families under study. A budget is a source of information on the basis of which it is possible to constitute groups, make comparisons and induce behaviours. The absence of a budget, according to Le Play, meant important information was lost (Le Play, 1989). The budget as a tool for forecasting and monitoring revenue and expenditure is therefore a means, in the case of exhibitions, of accumulating specific knowledge with experience. This accumulation is favoured by rules, procedures and structures, including those of accounting, imported from public accounting.

\subsubsection{Categorising expenses to understand behaviours}

The accounting information system, drawn from the public accounting model, enabled information to be accumulated on the consequences of decisions taken on expenditure and revenue. This knowledge was useful in the long-term for drawing up the budgets of future Exhibitions. The information system made this possible through reporting documents and through the statistics produced. The accumulation of knowledge may be placed on two levels (Cyert et March, 1992):

- on the one hand, in relation to the key variables specific to an exhibition: the amount of 
exhibition space needed and the number of visits. The edited statistics contributed a great deal to this type of learning by enabling the number of entries in given categories of visitors over a given period, the participation of the nations, and the movements of the foreign and domestic populations engendered, etc. to be compared;

- on the other, financial reporting enabled the consumption of the financial resources needed to hold an exhibition to be monitored. The principles of public finance were helpful in this: the documents relating to the budgets of the Exhibitions applied the principle of speciality which meant classifying the nature of expenditure by headings.

More generally, the budget procedure enabled knowledge of the environment to be accumulated. Past events and statistics made for a better understanding of the environment of an Exhibition in terms of visitor behaviours, expectations with regard to entertainment, and the means of transport used. In the particular case of the first two Exhibitions where a behaviour in recreational habits had to be created, statistics were a means of assessing the endorsement of the working population, for example to this type of event.

The contribution of the accounting information system in the accumulation of specific knowledge can be interpreted as a monitoring system (Feldmann and March, 1991; March, 1991): it is a question of understanding organisational methods through the accumulation of expenses and the generation of revenue. Accounting information where the statistics produced enable the taking of future decisions (in the case of a new Exhibition to organise), and an understanding of the environment that will be encountered. This monitoring is all the more important since mounting an exhibition is achieved within a relatively short space of time and requires specific, varied knowledge:

" the multiplicity of the questions that arise both rapidly exceed the efforts of the people occupied in the general organisation. The directors of the main departments, absorbed by the innumerable tasks that are so urgent they cannot be postponed, cannot create the concertation that should preside over such a complex piece of work, whose various elements are tightly overlapping (Le Play, 1869, p.269)».

\subsubsection{Managing time}

The budgetary procedure can be assimilated into a type of budgetary control based on the one hand on the existence of detailed forecasts in accounting language that cover all the activities of the Exhibition and on the other, on the production of inventories that compare forecasts and realities (Berland, 1999). When attempting to analyse the role of the budget, it is important to take into the account the style of strategic management exercised within the organisation (Berland, 1999).

The type of style to which one could attribute the case of the organisation of Universal Exhibitions would be 'strategic planning' as identified in Goold and Campbell's typology (1987). The latter takes into account the influence of the centre on planning and control. In the case of the Exhibitions, the involvement of the centre in planning is strong because decision-making was centralised, but financial control is not exercised to the extent that the only commitment to cost was a moral one. As such, control was fairly relaxed ('flexible strategic' control influence') with the control variables defined during the evaluation phase. They covered time limits (with the overall budget calculated on a yearly basis), the probable costs of each aspect of the Exhibition (buildings, conferences, entertainment...) and revenue (to be assessed at the outset). But there was very little formalisation of divergence, and reporting served mainly to ensure an accumulation of information on the action taken and the environment.

The role of the budget may be analysed essentially in terms of planning. It served in the evaluation and authorisation of expenditure (Berland, 1999), and in coordinating functions in order to keep to schedule. It fulfilled the organisers' need to see how the project was evolving, and to understand the financial dimension of this evolution and in the longer term, to learn lessons that would be useful when planning future exhibitions and forecasting expenses and revenue. This accumulation of knowledge resulted in learning about the creation of an Exhibition in that the commissioner or the president of the commission 
wrote a final report on the finished exhibition that dealt with these concerns and highlighted the choices made and the results obtained.

During this period, where lack of experience made the conception and realisation of the Universal Exhibitions difficult, an accounting system was built based on the principles of public finance that would lead to the creation of the Exhibition whilst accumulating useful knowledge. The role of learning played by accounting during this period was fundamental from one Exhibition to another and for the following period. The accumulation of experience led to the accounting tool assuming a new, more political role.

\section{Accounting in a rationalization role in the Universal Exhibitions of the 3rd Republic $(1878,1889$ and 1900)}

The events accompanying the fall of the Second Empire left France in a sorry state. The Universal Exhibitions therefore became a means of reaffirming the country's economic and political grandeur. Despite the change of political regime, there remained great continuity in the administration of the Exhibitions and in the men in charge of organising them. However, many changes took place during this period regarding the intensity of adhesion to the project and in the accounting system and its main role.

\subsection{Decision-taking and organisational incertitude in the Universal Exhibitions of the 3rd Republic (1878, 1889 and 1900)}

The three Universal Exhibitions organised with the return of the Republic demonstrate the Government's wish to disinvest in the financing of these events. The State's contribution was gradually reduced to $20 \%$ for the 1900 Exhibition and the rest of the funding came from private subscriptions (through the creation of a guarantee association). This method of financing was adopted by the 1889 Exhibition Commission to " constitute not only a financial body, but above all an instrument of propaganda that would encourage the active and vigilant cooperation of commerce and industry to ensure the success of the enterprise [and] save the State expenditure (Picard, 1891, p.310) ». The Government's disinvestment coincided with a return to strict parliamentary control cancelling all the executive power of the Commission in charge of the organising the Exhibitions.

On the basis of the first two Exhibitions, experience was accumulated without, for all that, erasing the uncertainty inherent in the consequences of the decision. On the other hand, with the return of parliamentary debate, criticisms on the validity of holding a Universal Exhibition in Paris emerged.

\subsubsection{From economic objective to social dimension: the search for meaning}

With the return of the 3rd Republic, the strict return to parliamentary control saw dissenting opinions as to the utility of organising Universal Exhibitions emerge. The criticisms concerned the financial implication of the State and the economic repercussions of these events. It would seem nonetheless that the social dimension of the Exhibitions was the one point of consensus amongst parliamentarians.

Criticisms relating to the State's financial implication were not new since from the first Exhibition onwards, the President of the Imperial Commission would have preferred exclusively private financing mirroring the British example. But this method of financing was impossible in France as he came to realise that, "we cannot hope to find sufficient resources outside the Government (Prince Napoleon, 1857: 136137)».

However, after the 1878 Exhibition which required the granting of extra loans to reach its goal, there was once again criticism of the State's financial commitment. The Exhibition of 1878 generated heavy expenditure because the problem of the foundations, unforeseen when the expenses budget was being drawn up, led to the expected 20 million francs expenditure being exceeded. Concluding the Report on this Exhibition, the general commissioner dismissed criticism saying:

«On this particular occasion, the government has first and foremost had to seek moral and political results. 
These results have been achieved to an unhoped-for degree. Who would dare say they have cost us too dear? (Krantz, 1881, p.501) ». The answers to this question were virulent, "indeed, as long as the State is paying, everyone allows themselves to ask everything of it without owing it anything in return. This attitude can be explained largely by the excessive expenses of 1878 and puts an end to the granting of unlimited credit by the Treasury for ever ».

However, although the financial involvement of the State in these Exhibitions was criticised, it was still considered to be the only means of ensuring they could be held since the rules of public accounting made it possible to control the use of the financial resources (Berger, 1885b) (no regulation of private accounting existed during this period (Lemarchand, 1995)).

The real fiscal and economic impact of an Exhibition was a subject of major disagreement although in the beginning, one of the aims was to boost domestic trade and industry. However, statistics drawn up for the Exhibition of 1867 and widely discussed during parliamentary debates in 1876, tended to point to a total lack of impact from the point of view of economic activity, and to increases in taxes and the cost of living. These same arguments came up again during the 1889 Exhibition:

"During the discussion, several members of the right [...], vigorously attacked the proposals of the Government and the Commission. Their main criticisms were founded on the following motives: the ineffectiveness of the international Universal Exhibitions for the development of both foreign and domestic trade; the excessive tax burden imposed on provincial tax-payers to obtain an illusory and temporary prosperity for a proportion of Parisian traders; uncertainty on the participation of foreign countries to the 1889 Exhibition; inadequacy of the studies done and the justifications produced by the Government; exaggeration of the spending and sacrifices of the State; the illusory nature of the contribution required of the guarantee association (Picard, 1891, pp.317-318)».

The impact of this focalisation on taxes should not be forgotten since it was a reminder of the obligation to find the means to pay the ransom demanded by Germany after the defeat of 1870. This imperative led to the creation of many taxes which were often mentioned in parliamentary debates. Since the debate grew more and more heated each time an Exhibition was planned, the Commission of the 1900 Exhibition included many economic and fiscal statistics in its arguments (growth of foreign trade, added-value on railway revenues, the financial contributions of visitors from the provinces and abroad). Nonetheless, the agreement on the laws of finance that opened credit from the State and the City of Paris were increasingly long in coming:

" the Government had therefore won support for its opinions. Impressive majorities had rallied round it in the Senate and the Chamber. But the project had remained before Parliament for almost seven months although the corresponding time-limit for the 1889 Exhibition had not exceeded three months (Picard, 1902, p. 246) ».

For the Exhibition of 1878, the Bill was passed in a month without opposition.

More generally, what we are seeing during the 3rd Republic was a change in the meaning given to Universal Exhibitions. With the boom in industry, science, trade and communications, the aim of the Exhibitions, which was to cover all spheres of human activity, was considerably extended:

"To the economic, political and didactic concerns that dominated the first exhibitions, was gradually added the desire, or more accurately perhaps, the need to entertain and to attract and retain the public's attention » (Bruhammer, 1983, p. 12).

As time went on, the principle of the Exhibitions was often challenged because of changes in the outside world. When the 1900 Exhibition was being set up, Meline's intervention in the Chamber (sitting of 16/03/1896) made reference to such changes:

«Universal Exhibitions were useful at a time when relations were difficult which meant that people were 
unfamiliar with one another's products. The Universal Exhibitions were a means of presenting one's products and they served as real sales offices. But with changes in relations, all the markets have become one universal market...».

Meline concluded from this that products from all over were now known to all and so the prime raison d'être of the Exhibitions had disappeared. So although the Universal Exhibitions put on under the Second Empire obtained support for their economic, political and social aims, support seemed only to be obtained for the social aim during this second period. The social aim nonetheless justified the financial involvement of the State. Indeed, during the 19th century, there was an affirmation of Government policy linked to changes in society, economic reality and the requirements of daily life (Sautel and Harouel, 1997). Since the Exhibitions dealt with such aspects by financing the organisation of these events, the State was transmitting a message of involvement in daily life and put forward a humanist vision of its action (Sautel and Harouel, 1997). Consequently, despite long parliamentary debates where criticisms of the validity of the exhibitions were expressed, they were always organised and public finance given, in the end.

\subsubsection{Variable degrees of uncertainty still present in the decision-making}

During the first two Exhibitions, the absence of models and previous experience created a lack of awareness of the consequences of a decision. On the other hand, during this second period, knowledge was available. This resulted in a better ability to envisage the results of decisions taken in terms of revenue and expenditure. However, risks still existed that it was difficult to foresee when the budget was being drawn up.

In general terms, uncertainty on the consequences of a decision was reduced compared to the preceding period. From the point of view of the evaluation of revenue the main component of which was the tickets sold, a behaviour was created during the first two Exhibitions. The exceptional nature of the Exhibitions was such that Parisians in particular and the French in general, showed increasing interest in these events and no longer hesitated to buy an entrance ticket or to subscribe to the guarantee association. The latter, created for the Exhibitions of 1889 and 1900 were a resounding success and released financial resources which gave the organisers a certain freedom of action. The organisers could therefore realistically count on a certain number of visits and a certain volume of revenue:

« The product of the entrance fees which only amounted to 10756000 francs in 1867, had reached 12428000 francs in 1878 despite the profusion with which free tickets had been issued. Since 1878, the taste for travel and the ease with which it could be accomplished had developed considerably. Transport networks had been significantly extended and the Government intended, moreover, to limit free entry to staff and exhibitors. It was therefore not unreasonable to count on revenue of 14500000 francs (Picard, 1891, p. 313)».

The evolution in living conditions and the state of development of the national rail network increased the accessibility of the Exhibitions to the greatest number of people and reduced uncertainty surrounding potential revenue:

«Since the Exhibition of 1889, transport had been developed and improved both in France and abroad. More and more people were becoming used to travelling. Fares had been considerably reduced especially within France after the partial suppression of the heavy tax that had previously hampered high-speed travel (Picard, 1902, p. 176)».

The development of transport systems, for example, was a recurring argument from 1878 onwards. However, budgets were finally only based on entry forecasts purposely reduced so as to take a certain degree of uncertainty into consideration.

Nonetheless, uncertainty could not be banished completely. It could even prove extremely prevalent and absorb the margins of financial security created during the elaboration of the overall budget. A first example of this form of uncertainty was noticeable in the case of the 1878 Exhibition. With time, the scale 
of the Exhibitions increased (on account of the importance bestowed on entertaining the public), and the need for land grew considerably whilst available space in Paris shrank. Sites mushroomed and had to be serviced. Overspending on the 1878 Exhibition stemmed from an insufficient understanding of the risks linked to the selected sites:

" the Trocadero buildings cost more because the extent of the need for consolidation of the land due to the existence of quarries underneath was inaccurately assessed since no survey had given cause to suspect the extent of this lamentable state of affairs (Krantz, 1881, p. 50)».

A second example is the Exhibition of 1889: the theme adopted was that of the centenary of the French Revolution. However, this provoked strong reactions abroad and led to a form of boycott on the part of foreign exhibitors which had an impact on the optimisation of the space. Lastly, uncertainty can be a question of totally unpredictable economic events. This was the case during the 1900 Exhibition where unfavourable circumstances such as the war in South Africa, events in China and the high summer temperatures "prevented the number of visitors being as high as the Exhibition's organisers had legitimately expected. The impact of these circumstances on ticket sales was still more significant (Picard, 1902, p.182)».

The Universal Exhibitions organised under the 3rd Republic were the complete opposite of the Exhibitions of the preceding periods. The return of parliamentary debate made it possible for the economic justification of these events to be questioned. A consensus could not be taken for granted. It had to be obtained politically with the organisers putting forward arguments to justify their choices. Besides, the accumulation of experience reduced the uncertainty present at the outset in assessing the consequences of a decision. Decision-taking in creating the Exhibitions therefore took on a political dimension: justifying budget choices and directing action to obtain Parliament's approval (Burchell \& al., 1980).

The principles of public finance were still applicable because of partial public subsidies. In addition, during the first two Exhibitions, the accounting model had been adapted to the constraints of organising a project of this nature. This model evolved again now as a result of the political dimension of decisionmaking (in relation to the strengthening of the budgetary procedure). The accounting and financial system now takes on the role of a « rationalization machine » as used by Burchell \& al., (1980).

\subsection{Evolution of the role of accounting towards rationalization in the Universal Exhibitions held under the 3rd Republic}

The accounting model adopted for the organisation of the Universal Exhibitions under the 3rd Republic stems from the accounting model adapted during the first period. But this model takes into account modifications to the rules of public finance linked to the return of the Republic. The application of stricter rules in the organisation of the Exhibitions coincided with the need to legitimize the utility of the Exhibitions and the use of the funds that were made available. The role of accounting became increasingly political: it was a question of rationalizing in retrospect the decision to hold an Exhibition.

\subsubsection{Evolution of the public accounting model: towards stricter control}

The arrival of the 3rd Republic gave parliamentary control back the importance that had been taken away from it by the Second Empire. The successive commissions in charge of the organisation of the Universal Exhibitions lost the prerogatives they had possessed under the preceding regime. They were responsible for making proposals and carrying them out under the control of Parliament. The State granted finance and the general commissioner had to account for the use he had made of these financial resources. Budgetary procedure still occupied a central place in the administration of the Exhibitions. It took on new characteristics, however, because of the change of political regime. The same was true of the rules of public accounting that were adopted. This evolution influenced the accounting information system. 


\subsubsection{The strengthening of budgetary procedure}

In accordance with the procedure laid down for the preparation of the State's overall budget, the strict return to parliamentary control made the constitution of a preparatory commission compulsory as soon as the Decree announcing that an Exhibition was to be held was proclaimed, (Marion, 1931; Kott, 2004; Picard, 1901). This commission had a purely consultative role. It was responsible for discussing and calculating the cost of future action in an overall budget in the form of broad headings (in respect of the principles of annual and speciality budgeting). This budget was then submitted for examination by the budgetary commission. This phase was completed when the project was confirmed and an agreement was approved. Such validation was obtained through parliamentary debate and vote. The necessary financial resources were then obtained through the declaration of a Finance Act. The preparatory commission did not carry out the project but handed over to a new commission placed under the responsibility of a minister (for Trade, Agriculture or the Fine Arts) with a general commissioner placed at its head.

The commission in charge of the organisation of the Exhibition then proceeded with a detailed analysis of the expenses and revenue contained in the overall budget with the aim of producing an annualized budget. This forecast was based on a schedule showing the planned progress of the project and served as a control budget when carrying out the retrospective audit demanded by public finance. The credits granted had to be spent in the course of the year in order to respect the annual nature of the budgets. Lastly, to monitor the execution of the budget and in accordance with the rationale of public financial control that aims to avoid overspending, compulsory financial reporting enabled the reality to be compared with the budget at frequent intervals. Added to this reporting were the obligations to render the accounts (a report detailing revenue and expenses must be presented to the President of the Republic; this report was then the subject of a publication intended for the Senate and the Chamber of Deputés). This report was reviewed once more after the liquidation period.

\subsubsection{The move towards bureaucratic accounting}

During this period, the public accounting code was revised twice - in 1878 and 1884 (Magnet, 1995). These revisions were integrated into the accounting system for the Exhibitions but the main rules remained unchanged. The general commissioner took on all the responsibilities for the orders to pay within the limit of the credits granted. Each order to pay had to be separated from its settlement, so the general commissioner had to send an order to pay to the payer and the accountant had to check the supporting documents. The supporting document was an indispensable element. No payment could be made without a mandate: the organiser transmitted a supporting document to the payer without which nothing could proceed. This meant that in the accounts and summary statements, mention had to be made of receipts for income, the stakeholders had to be named, and authorisation for expenditure and payments had to be demonstrated.

The 1878 Exhibition was different from the other Exhibitions in that its accounting and finance were governed by regulations:

- The financial regulations set out « the guiding principles of the organisation of the revenue and expenditure departments ».

- The accounting regulations "apply in particular to the administration of the Exhibition, (give) details of the forms adopted for the liquidation of expenditure ».

With the exception of the distinction made for the Exhibition of 1878, a single set of regulations was usually drawn up. The table below sets out the content of the regulations of the Exhibitions of 1867 and 1889. The 1867 regulation includes 24 articles whilst that of 1889 has 34 and they are much more detailed. Both cover the budget procedure, the organisation of the accounts books, accounts entries, the supporting documents, and summary statements. However, the regulations of 1889 contain much more detail and prescribe many more checks, thereby emphasising the bureaucratic side to the organisation. The documents show an extremely hierarchic and centralised type of organisation where all decisions and 
writing are checked and authorised.

\section{Table 1 : Accounting codes for 1867 and 1889 Exhibitions}

\begin{tabular}{|c|c|}
\hline $\begin{array}{l}\text { Accounting Regulations for the Exhibition of } 1867 \\
\text { Proposed accounting regulations governing revenue and expenditure dated } \\
\text { 1865. National Archives } F^{12} \text { 2993; report on the organisation of the } \\
\text { Exhibition of } 1867 \text {. }\end{array}$ & $\begin{array}{l}\text { Accounting Regulations for the Exhibition of } 1889 \\
\text { Proposed accounting regulations under the letterhead of the Ministry for } \\
\text { Trade and Industry. National Archives } F^{12} 3816 .\end{array}$ \\
\hline $\begin{array}{l}\text { - Title 1: The revenue and expenditure budget } \\
\text { Origin of the funds and object of the expenditure (article 1), } \\
\text { attribution of the revenue linked to the Exhibition to a } \\
\text { current account with the Crédit Foncier de France (article 2), } \\
\text { procedure for settling expenses and means of settling minor } \\
\text { expenses (article } 3 \text { ). } \\
\text { - Title 2: The liquidation of expenditure . } \\
\text { Measures concerning the remuneration of the members of } \\
\text { the Imperial Commission (article } 4 \text { ), administrative } \\
\text { procedures governing contracts, submissions dealt with and } \\
\text { agreements (article 5), ban on staff having anything to do } \\
\text { with contracts or supplies (article } 6 \text { ), procedure for } \\
\text { managing expenditure, wages and salaries (article } 7 \text { to 12). } \\
\text { - Title 3: The payment of expenses } \\
\text { The settlement of expenses necessarily requires a mandate } \\
\text { (article 13), their payment is made by a cheque drawn on the } \\
\text { Crédit Foncier (article 14), list of the clauses the mandates } \\
\text { must mention (article } 15 \text { ), list of supporting documents to be } \\
\text { presented for each payment (article } 16 \text { ), classification of the } \\
\text { various payments in full, deposit, balance, advance (article } \\
\text { 17), regulation of the various payments previously } \\
\text { mentioned (articles } 18 \text { to } 21 \text { ). } \\
\text { - Title } 4 \text { : Double-entry accounting, books to be kept and } \\
\text { balances to be drawn up (article } 22 \text { ). } \\
\text { - Title 5: Checking of the accounts by the finance committee } \\
\text { (article } 23 \text { ). } \\
\text { - Title } 6: \text { The general account of revenue and expenditure to } \\
\text { be established by the general commissioner (article } 24 \text { ). }\end{array}$ & $\begin{array}{l}\text { - General measures } \\
\text { These general measures describe the sources of finance, the } \\
\text { allocation of revenue, and the attribution of the final profit or } \\
\text { loss to the State (article 1), the destination of extra expenses } \\
\text { (article 2), sources of credit (article } 3 \text { ), the funding of the } \\
\text { medical service (article 5). } \\
\text { - Revenue. } \\
\text { This Chapter lists the revenues that the Exhibition must } \\
\text { generate (article } 6 \text { ), the measures relating to free entry } \\
\text { (article } 7 \text { ) and to the revenue from hiring sites and various } \\
\text { licences (article } 8 \text { ), the summary statements of revenue to be } \\
\text { drawn up (article 9). } \\
\text { - Expenses. } \\
\text { This chapter determines the procedure for the annual } \\
\text { demand for credit (article } 10 \text { ) and the establishment of } \\
\text { annual budgets (articles } 11 \text { to } 13 \text { ), the method of determining } \\
\text { remuneration (article } 14 \text { ), the repartition of authorized } \\
\text { signatures depending on the sum of expenses (article } 16 \text { ), the } \\
\text { procedure for regulating expenses (articles } 17 \text { to } 26 \text { ). } \\
\text { - Accounts of the General Financial Management } \\
\text { Department and the General Managements of the } \\
\text { engineering and operations managements. } \\
\text { This Chapter governs the keeping of the books and } \\
\text { determines their organisation as well as the transfer of the } \\
\text { accounts (article } 27 \text { ), the accounts of the other management } \\
\text { departments(article } 28 \text { ), the summary statements to be drawn } \\
\text { up, their frequency and their addressee (articles } 29,30,31 \text { ), } \\
\text { the method of drawing up the inventory of moveables and } \\
\text { materials (articles } 32,33 \text { ), measures concerning contracts } \\
\text { (article } 34 \text { ). }\end{array}$ \\
\hline
\end{tabular}

The checks on accounting movements gave rise to a need for numerous reporting documents which meant the accounting information system had to be capable of generating an increasing amount of information.

\subsubsection{A changing accounting information system}

The exhibitions organised under the Second Empire provided experience of the organisation of an accounting information system. It still served the purpose of processing economic information in order to assist in forecasting and provide reporting information and statistical data. The major difference between the centralizing system of 1867 and that of 1889 lies in the dissociation between the Journal (management Journal) and the Ledger.

The accounting information system changed mainly in the accounts and in the terms used. The influence of industrial accounting practices was followed by the influence of the Italian school of public accounting. The latter emphasised the administrative role of accounting after Guiseppe Bornaccini who laid down rules and fixed, unalterable and rational rules and principles (Vlaeminck, 1979). These rules were formalised in accounting regulations. Similarly, Italian accounting uses the terms "doit" and "avoir" specifically in its important theories (from 1840 onwards) (Vlaeminck, 1979). These terms were also used 
in the Ledger of the 1889 Exhibition. Moreover, the classification of the accounts adopted during the 1889 Exhibition includes budget, balance and public treasury accounts, emphasising once again the influence of the Lombard school, led by Francesco Villa, who recommended classification into three groups: 'personal accounts', 'agents' accounts' and 'summary accounts', including the opening balance account, income and expenditure accounts, and the closing balance account (Vlaeminck, 1979).

The influence of the Italian School can also be seen in the use of accounts such as the "Public Revenue account », "guarantee association » and «City of Paris » accounts which can be traced back to the work of Guiseppe Cerboni, since he recommended opening an account for each of these natural or legal entities, capable of rights and obligations either themselves or through their representatives (Vlaeminck, 1977). This influence is all the more interesting since Cerbonni defines the aim of accounting as being the observation and registration of the acts of these various administrative bodies (Gomberg, 1929). Above all, it was a question of controlling and supervising the action of agents and therefore occupied an opposing position to that of the owner (in this case the resource providers: the State, the City of Paris and the guarantee association) and the administrator of these resources. It is therefore possible to create a link with budget forecasts (expected, organised and actual expenditure and revenue) and to highlight the responsibilities of the various bodies in the administration (Gomberg, 1929, p. 28).

Lastly, this information system produced reporting documents that can be placed in one of three categories:

- At a more general level, with reference to the budget, a link is made between the forecast and actual revenue and expenses in order to identify possible excesses or insufficiencies.

- Specific documents are established to assess the expenditure of an accounting exercise that has been or will be, liquidated, or which is yet to come. Such monitoring can be carried out by the ministries that provide the resources or with reference to the past, the current, or a future exercise.

- Regular closures of the cash books highlight the sums ordered and settled, the sums to be used, and the sums used.

\subsubsection{The roles fulfilled by the accounting model set up under the 3 rd Republic}

Although the first role of the accounting system was that of a 'learning machine', it gave way to that of a 'rationalizing machine'. Against the background of a return to parliamentary debate that called into question the utility of an Exhibition, and public and private financing that created a double agency relationship, accounting acquired a new role. The quality of the administration and the choices that were made had to be demonstrated and this engendered the role of rationalizing action.

\subsubsection{Rationalizing the reliability of the organisation in charge of an Exhibition}

The accounting information system adopted during the Exhibitions held during this period was still intended to give economic visibility to the consequences of decisions and to enable the governance of the

organisation. It still offered a centralised representation of the organisation, divided into functions. Within these functions, coordination was vertical. The departments, (the accounts department, for example) were run by a limited number of managerial employees in accordance with an authoritarian operating model formalised by strict rules and procedures (Krantz, 1881) which were themselves placed under the supervision of the commissioner (as the regulations for the accounts of the Exhibitions show). This centralisation allowed an increased number of sub-ledgers to be created as and when they were needed. In this respect, it would seem interesting to underline the fact that the centralisation of the organisation, the budgetary procedure and the accounting procedures contributed to removing the ephemeral nature of the organisation and indicated an organisation that was under control despite the inherent uncertainty of the project that was to be managed. Indeed, a new level of analysis can be introduced concerning the utility of the budgetary procedure in the governance of the organisation of the Exhibition. The budgetary procedure, by planning the action to be taken and the expenditure needed within a given time-frame, lends stability to the organisation (Mintzberg, 2004). Such stability is very important in this type of event 
which is wide-ranging in financial, technical and human terms. It also enables risks and unforeseen events to be controlled and to run a temporary organisation along the same lines as an ordinary company. The budgetary procedure enables the objectives to be quantified and programs of action to be defined and coordinated, as has already been indicated. Lessons learnt from preceding Exhibitions help define and coordinate action:

"The judicious running of the main industrial operations should be inspired by the same principles everywhere. As unalike as these operations may appear at first sight, they all, in the end, come under the same regulations, discipline and method, and only in this way may they be brought to a successful conclusion. From this point of view, perhaps an honest account of what was done for the 1878 Universal Exhibition will provide useful food for thought (Krantz, 1881, p. V) ».

Placing financing within the principals of annual and speciality accounting strengthen an organisation's stability by preventing major changes. This level of analysis concords with Fayol's vision of planning (1999). Planning enables clear directions to be defined, within which resources are used in a coordinated manner. It ensures that an even course is maintained despite changes in the governing authority (political instability of the 3rd Republic). Lastly, highly formalised procedures enable action and behaviours to be made more "rigid», thereby preserving and reinforcing the stability of the system (March et Simon, 1991). The protected and stable environment in which a project is mounted (under State supervision) is particularly favourable in this respect.

\subsubsection{The rhetoric of good management}

Concern to legitimize the reliability of the organisation in charge of an Exhibition was combined with the rhetoric of good management: this meant rationalizing the action taken by the organisers. Indeed, in terms of agency theory, the shift of opinion in favour of private finance that was demonstrated by the creation of guarantee associations reinforced the need to account for the use of financial resources. In this context, the organisers had to try to demonstrate good management of the funds placed at their disposal by the private sector. By producing a large quantity of financial reporting and statistics, the budgetary procedure and the accounting information system served to show that the organisation was completely under control (Mintzberg, 2004). Good management rhetoric emerged: information produced assumed a symbolic role (Feldmann and March, 1991) that could be seen at several levels:

- by appointing members from public government, the State reinforced the legitimacy of the administration of the Exhibitions since according to Weber (2003), civil servants possess a strong sense of honour and integrity, two qualities that were much prized where the Exhibitions were concerned since resources had been made available (Berger, 1885b).

- The importing of codified accounting regulations although none existed in the private sector, was another signal to the public of good management.

In more general terms, the production of financial reporting, statistics and procedures constitutes a ritual means of ensuring the existence of appropriate attitudes to decision-taking. They reinforce the perceived competence of the organisers who appear to be taking decisions as "good deciders " should. This is associated with the belief that the quality of the decision depends on the quantity of information produced. The result is confidence in the fundamental rightness of the decision. Information is therefore a means of symbolising the legitimate nature of the process, the value of the decision-makers, and the good management of the organisation.

\subsubsection{A retrospective justification of utility}

After the appointment of the administrators and the nature of the decisions taken, a third level of rationalization concerned the rightness of holding Exhibitions in Paris in the first place. Indeed, the 
decision to hold Exhibitions at all under the 3rd Republic was called into question. To respond to this lack of consensus, it became important to justify them retrospectively. This was done through reports written after the event. The reports relate how the overall budget was drawn up, how the assessments of revenue and expenditure were made, and what hypotheses were used to understand the environment. They became the means of justifying budgetary choices and responding once again to criticisms made in parliamentary debates. It was also the means of comparing the final accounts with the budget so as to justify the use made of the credits.

The Exhibitions generated a great deal of financial reporting and numerous statistics, the nature of which changed. The statistics produced, for example, now concerned the economic and fiscal impact of the Exhibitions in response to the concerns expressed in the parliamentary debates. For example, the Report of the 1900 Exhibition included an analysis of the results of the Exhibition in terms of tax revenue, railway traffic and revenue, revenue from theatre, banking and hotel activities, spending by foreigners in Paris, and all over a three-year period.

This information was produced both to rationalize the utility of the past Exhibition and to support the decision to hold it as well as to justify the holding of future events. The information sought to influence in advance parliamentary debate and the vote that would take place when a new Exhibition project was mooted: it was what Feldmann and March (1991) qualify as strategic disinformation, which in this particular case, had a political dimension (the country's influence abroad).

\section{Conclusion}

The Universal Exhibitions organised in Paris during the second half of the 19th century under the control of the French Government were firstly a fertile field of investigation for the hitherto relatively littleexamined study of public accounting practices. From this point of view, the Exhibitions held in Paris highlighted practical adaptations of the legal regulations within the context of a change of political regime. In addition to the adaptation of an accounting system, the case of the Paris Great Exhibitions highlights the changing roles fulfilled by this system over time. The learning role stemmed from an appropriation of the principal objective of the public accounting system for the purposes of project management. At the time, there were no guidelines available to help the organisers so they had to be created. As for the role of rationalization, this emerged once experience had been acquired and was a question of confirming the expertise of the organisers.

\section{Bibliography}

Archives Nationales

Exhibition universelle de 1855 : Archives Nationales $F^{12} 2904$; Archives Nationales $F^{12} 2905$; Archives Nationales $\mathrm{F}^{12} 2906$

Exhibition universelle de 1867 : Archives Nationales F ${ }^{12}$ 2918; Archives Nationales F ${ }^{12} 2995$; Archives Nationales F 12 2999 ; Archives Nationales $F^{12} 3002$; Archives Nationales $F^{12} 3151$; Archives Nationales $F^{12} 3153$; Archives Nationales $F^{12} 3154$; Archives Nationales F ${ }^{12} 3155$; Archives Nationales F ${ }^{12} 3157$; Archives Nationales F ${ }^{12} 3159$

Exhibition universelle de 1878 : Archives Nationales F 123217.

Exhibition universelle de 1889: Archives Nationales $\mathrm{F}^{12} 3803$ A et B ; Archives Nationales $\mathrm{F}^{12} 3816$; Archives Nationales $F^{12} 3817$; Archives Nationales F ${ }^{12} 3818$; Archives Nationales F ${ }^{12} 3970$; Archives Nationales $F^{12} 3987$; Archives Nationales F ${ }^{12} 3988$; Archives Nationales F ${ }^{12} 3993$; Archives Nationales F ${ }^{12} 4050$.

Exhibition universelle de 1900 : Archives Nationales F ${ }^{12} 4417$; Archives Nationales F 124180.

Bibliothèque des Arts Décoratifs

Prince Napoléon (1857), Imperial Commission - Rapport sur l'Exhibition universelle de 1855 présenté à l'Empereur par SAI le prince Napoléon, président de la commission, Imprimerie Impériale. 
Le Play F. (1869). Imperial Commission - Rapport sur l'Exhibition universelle de 1867 à Paris, Imprimerie Impériale.

Krantz J. B. (1881). Ministère de l'Agriculture et du Commerce - Rapport administratif sur l'Exhibition universelle de 1878 à Paris, Imprimerie Nationale.

Berger G. (1885a). Exhibition universelle de 1889 - considérations générales sur son organisation, ed. Berger-Levrault et Cie.

Berger G. (1885b). Exhibition universelle de 1889 - projet d'organisation financière, ed. Berger-Levrault et $\mathrm{C}^{\text {ie }}$.

Picard A. (1891). Exhibition universelle de 1889 - Rapport général, Imprimerie Nationale.

Picard A. (1902). Exhibition universelle de 1900 - Rapport général administratif et technique, Imprimerie Nationale.

Autres références

Berland N. (1999), A quoi sert le contrôle budgétaire ?, FCS, vol 2, n³, septembre 1999, pp. 5-24.

Bruhammer Y. (1983), «Comment fait-on l'exposition des Expositions?» in Le livre des Expositions Universelles 18511989, ed. Herscher.

Burchell S., Clubb C., Hopwood A., Hughes J. \& Nahapiet J. (1980), 'The roles of accounting in organizations and society', Accounting Organizations and Society, vol 5, n 1, pp. 5-27.

Cyert R. et March J. (1992), A behavioural theory of the firm, (New-York: Blackwell).

De Maurepas, A. (1998), Economie et finances au 19ème siècle - guide du chercheur 1789-1870, (Paris : CHEFF).

de Swarte V. (1885), Essai sur l'histoire de la comptabilité publique en France, Bulletin de la Société de Statistique de Paris, vol 26, n 8 , août, pp. 317-352.

Fayol H. (1999), Administration industrielle et générale, ed. Dunod

Feldman M.S. et March J. G. (1991), «L'information dans les organisations : un signal et un symbole » in Décisions et organisations sous la direction de J. G. March, Editions Organisation, pp. 255-275.

Gomberg L. (1929), Histoire critique de la théorie des comptes. Thèse de doctorat ès sciences économiques de l'Université de Genève.

Goold M. and Campbell A (1987), Strategies and styles: the roles of the center in diversified corporations, Basic Blackwell.

Hopwood A. (1987), 'The archaeology of accounting systems', Accounting Organizations and Society, vol. 12, n³, pp. 207-234.

Kott, S. (2004) Le contrôle des dépenses engagées - évolution d'une fonction, (Paris : Ministère de l'Economie, des Finances et de l'Industrie, coll. Comité pour l'histoire économique et financière de la France).

Lemarchand, Y. (1995) 1880-1914, l'échec de l'unification des bilans. Le rendez-vous manqué de la normalisation, Comptabilité, Contrôle, Audit, 1(1), pp. 7-24.

Lemarchand, Y. (1999) Introducing double-entry bookkeeping in public finance, a French experiment at the beginning of the eighteenth century, Accounting, Business and Financial History, 9(2), pp. 225-254.

Magnet J. (1995), Les règlements généraux sur la comptabilité publique au 19 ème siècle, Actes du colloque «comptabilité publique - continuité et modernité », pp. 31-39.

March J. G. (1991), « Systèmes d'information et prise de décision : des liens ambigus » in Décisions et organisations sous la direction de J. G. March, Editions Organisation, pp. 231-254.

March J. G. et Simon H. (1991), Les organisations, Editions Dunod.

Marion, M. (1928), Histoire financière de la France depuis 1715, tome V 1819-1875, (New York: ed. Burt Franklin).

Marion, M. (1931), Histoire financière de la France depuis 1715, tome VI 1876-1914, (New York: ed. Burt Franklin).

Michaïlesco C. (2007), Contrôle de gestion de projet au $19^{\mathrm{ème}}$ siècle, le cas des Expositions universelles parisiennes (18551900), Comptabilité, Contrôle Audit, tome 13, vol. 2, pp. 31-52.

Mintzberg H. (2004), Grandeur et décadence de la planification stratégique, Editions Dunod.

Nikitin M. (2005), «Edmond Degranges père et fils, de la tenue des livres à la comptabilité » in Les grands auteurs en 
Comptabilité sous la direction de B. Colasse, éd. EMS.

Orsoni, G. (1994) Equilibre budgétaire : histoire d'une pratique, in: L. Tallineau (Eds.) L'équilibre budgétaire, pp. 5-21 (Paris: Economica, coll. Finances publiques).

Rebérioux, M. (1983). "Les ouvriers et the Exhibitions universelles de Paris au 19ème siècle, in: Le livre des Expositions Universelles 1851-1989 (Paris : Herscher).

Sautel G. et Harouel J. L. (1997), Histoire des institutions publiques depuis la Révolution française, Dalloz, 8 ème éd.

Thuillier, G. (1999), Pour une histoire de la bureaucratie en France, (Paris : Ministère de l'Economie, des Finances et de l'Industrie, coll. Comité pour l'histoire économique et financière de la France).

Vlaemminck J. (1979), Histoire et doctrines de la comptabilité, Editions Praguos.

Weber M. (2003), Le savant et le politique, (Paris : La découverte / Poche coll. Sciences Sociales).

Diagram 1 : Centralising System for the Exhibition of 1867

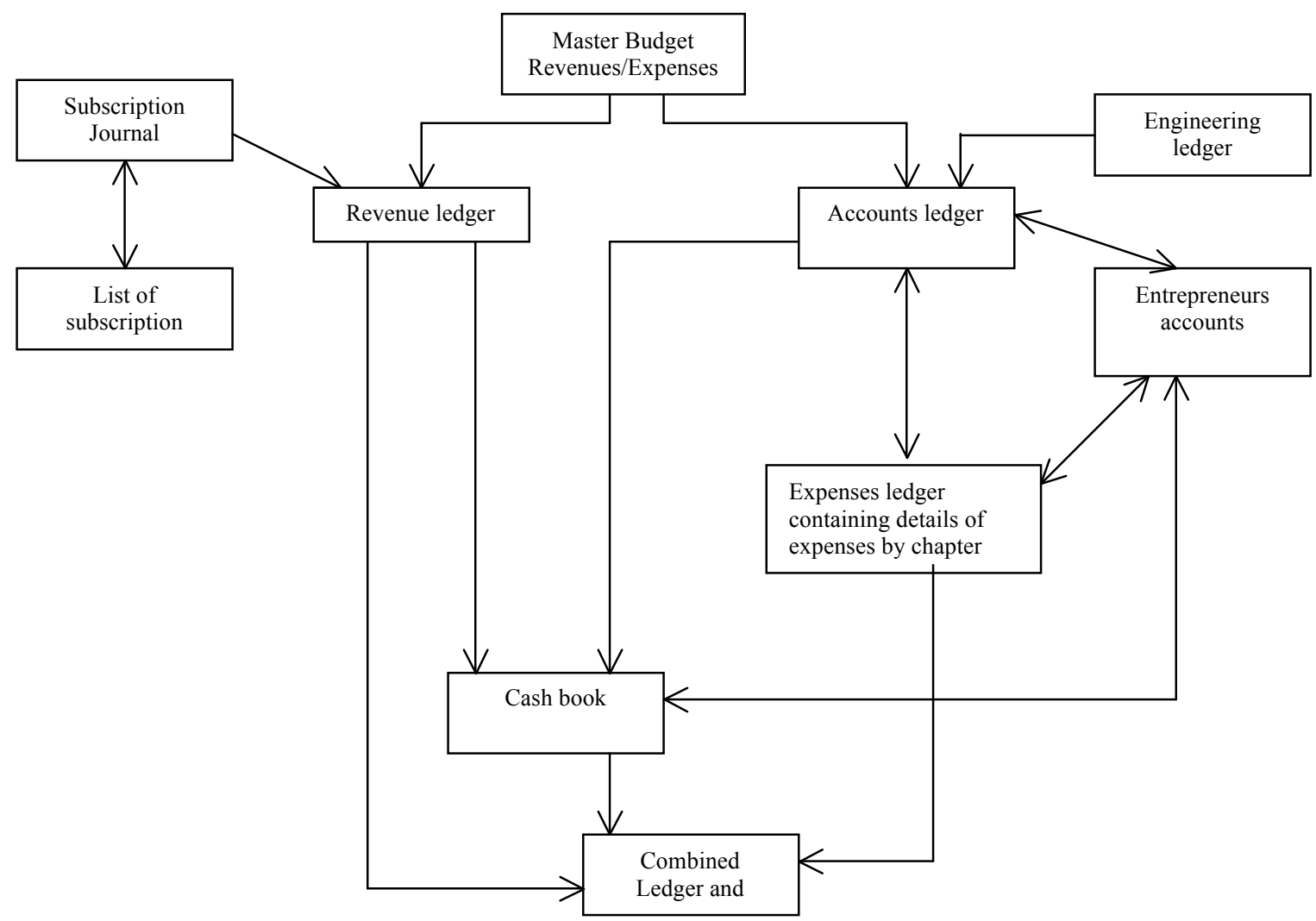

